\title{
Akaniaceae: a new family record for flora of India and lectotypification of the name Bretschneidera sinensis
}

\author{
Vikas Kumar ${ }^{1}$, Sudhansu Sekhar Dash ${ }^{2 凶}$, Samiran Panday ${ }^{1}$, Subhajit Lahiri ${ }^{1}$, \\ Bipin Kumar Sinha² and Paramjit Singh ${ }^{2}$
}

${ }^{1}$ Central National Herbarium, Botanical Survey of India, Howrah - 711 103, India

${ }^{2}$ Botanical Survey of India, CGO Complex, Sector-1, Salt Lake, Kolkata - 700 064, India

凶Corresponding author:ssdash2002@yahoo.co.in

\section{एकानिऐसी: भारतीय वनस्पतिजात के लिये एक नवीन कुल का अभिलेख एवं ब्रेटसनिडेरिया साइनेन्सिस नाम का लैक्टोटाईपीफिकेशन}

\author{
विकास कुमार, सुधांशु शेखर दाश, समीरन पांडे, सुभाजित लाहिड़ी,
} बिपिन कुमार सिन्हा एवं परमजीत सिंह

\section{सारांश}

ब्रेटसनिडेरिया साइनेन्सिस हेमस्ले, आईयूसीएन की संकटग्रस्त वृक्ष जातियों की लाल सूची में सम्मिलित इस जाति का संग्रहण भारत के अरूणाचल प्रदेश में र्थित नमदाफा राष्ट्रीय उद्यान एवं बाघ अभयारण्य से किया गया है, जो एकलप्ररूपी वंश ब्रेटसनिडेरिया एवं कुल एकानिऐसी का प्रथम वितरणपरक अभिलेख है । इस शोधपत्र में जाति का लैक्टोटाइपिफिकेशन कर ब्रेटसनिडेरिया साइनेन्सिस नाम के साथ वर्गिकी विवरण प्रस्तावित किया गया है ।

\section{ABSTRACT}

Bretschneidera sinensis Hemsley, an IUCN Red Listed Endangered tree species has been collected from Namdapha National Park and Tiger Reserve, Arunachal Pradesh, India which constitutes the first distributional record of the monotypic genus Bretschneidera and the family Akaniaceae in India. Lectotypification of the name Bretschneidera sinensis proposed here along with detailed taxonomic account of the species.

Keywords: Akaniaceae, Bretschneidera sinensis, New Record, Lectotypification, India

\section{INTRODUCTION}

Bretschneidera sinensis Hemsl., belongs to the family Akaniaceae, and is distributed in South and East China to Taiwan and N. Vietnam (Lianli Lu \& Boufford, 2005). Presently Akaniaceae is represented by two monotypic genera viz. Bretschneidera (Hemsley, 1891), and Akania
(J.D. Hooker, 1862). Earlier, both genera were described under the family Sapindaceae but subsequently, Akania was transferred to Staphyleaceae by Solereder (1892) and finally placed in a newly established family Akaniaceae by Stapf (1912). The taxonomic placement of the genus Bretschneidera has been debatable. Engler \& Gilg (1919) 
shifted the genus from Sapindaceae to Hippocastanaceae and later based on the presence of Myrosin cells in the bark, pedicels and petals, they (Engler \& Gilg, 1924) placed it in a new distinct family Bretschneideraceae under newly established suborder Bretschneiderineae of Rhoeadales. Hutchinson (1926) did not recognize the family Bretschneideraceae and transferred the genus back to the family Sapindaceae. Based on wood anatomical and molecular studies (Gadek \& al., 1992; Tobe \& Raven, 1995; Carlquist, 1996; Rodman \& al., 1996; Ronse \& al., 2002) and on morphological evidences Doweld (1996), Rodman (1991) supported distinctness of family Bretschneideraceae and Akaniaceae from Sapindaceae. More recently, Akaniaceae has been treated to include both the genera Akania and Bretschneidera (APG 1998, 2009 \& 2016, The Plant List, 2016, Christenhusz \& Byng, 2016).

The family Akaniaceae is characterized by medium to large sized trees with fibrous bark. Leaves alternate, pinnate; leaflets sub-opposite, entire or serrate or toothed; stipules minute. Inflorescences with axillary panicle or terminal racemes, bracts minute or lacking. Flowers actinomorphic or zygomorphic, bisexual. Calyx 5-lobed, imbricate. Petals 5, longer than sepals, clawed or slightly constricted at base, laciniate or emarginate at apex. Stamens 8-10, distinct, inserted at or near base of receptacle cup, filaments pubescent at base, anthers dorsi to sub-basifixed, versatile. Ovary sessile, surrounded by cupular tube, syncarpous, 3-locular, pubescent, placentation axile, ovules 2 per locule, pendulous, bitegmic; style simple, slender, curved. Fruit capsular, loculicidal, pear-shaped, three-celled, leathery, pubescent; seeds broadly ellipsoid, embryo straight, cotyledons thick.

During a recent plant exploration tour to Namdapha National Park and Tiger Reserve (NNPTR), Changlang district of Arunachal Pradesh, an interesting tree species with brilliantly coloured, showy flowers was collected. On consultation of literature (Santisuk, 1989, Chauhan \& al. 1996, Lu \& al., 1986, Lianli Lu \& Boufford, 2005) and critical study of herbarium specimens and images from multiple herbaria (ARUN, ASSAM, BM, $\mathrm{BSD}, \mathrm{CAL}, \mathrm{E}, \mathrm{GH}, \mathrm{IBK}, \mathrm{K}$ and $\mathrm{WU}$ ), the identity of the species has been confirmed as Bretschneidera sinensis Hemsl. The species is an IUCN Red Listed endangered species (Sun, 1998) and erstwhile reported from China, Vietnam, Taiwan and Thailand. The occurrence of this species constitutes a new record of the family Akaniaceae and genus Bretschneidera for flora of India and further extends the distribution of Bretschneidera sinensis Hemsl. north westwards from its present range.

\section{MATERIAL AND METHODS}

The present work is based on examination of live plants in field and study of the specimens available in multiple herbaria. The flowers were dissected from fresh material and photographed by Sony DSC-HX60V digital camera. The locality map is created by using software Arc Map 10.5, basic version. Multiple specimens and specimen images from different herbaria were studies to note the variations if any.

Typification: Hemsley (1891) cited two collections viz. A. Henry 10540 and 11651 from Yunnan (China) while describing Bretschneidera sinensis, and also provided an illustration t. 2708 in the protologue. During the search in multiple herbaria [ARUN, A, ASSAM, CAL, BSD, DD, WU, K, GH, IBK], we traced nine collections from E, K and CAL and GH [A. Henry 10540 (E), (K000681001, K), 00050654 (GH, image!); A. Henry 11651 (K000681002, K), (K000681003 K), (CAL0000024326, CAL) and 00050653 $(\mathrm{GH})$ ] which can be considered as original material together with the illustration number t. 2708. After critical examination of the original material, we found that specimen K000681002, is complete in all respect and well agrees with the protologue and thus designated here as lectotype of Bretschneidera sinensis as per Art. 9.12 of ICN (McNeill \& al. 2012.).

\section{KEY TO THE GENERA}

1a. Leaflets 7-30, serrate along margins; inflorescences axillary panicles; flowers actinomorphic, calyx 3-4 mm long Akania

1b. Leaflets 7-15, margin entire; inflorescences terminal racemes; flowers zygomorphic; calyx 15-25 mm long Bretschneidera

\section{TAXONOMY}

Bretschneidera sinensis Hemsl., Hooker's Icon. Pl. 28: t. 2708. 1891; S.Y. Lu \& al. in Quart. J. Chin. Forest. 19: 115-119. 1986; Santisuk in Nat. Hist. Bull. Siam Soc. 37(2): 173-176. 1989; L. Lianli \& Boufford in Fl. China 8: 197. 2005.

(Fig. 1-6)

Type: China, Yunnan, Szemao, 5000ft., A. Henry 11651 (K000681002!, Lectotype designated here); isolectotypes (K000681003!, CAL0000024326!, 00050653 (GH- image!; E!) 
Bretschneidera yunshanensis Chun \& F.C. How in Acta Phytotax. Sinica 7(1): 68. Pl.10. 1958. Types: China, Hunan, Wukang, Yunshan, 7 October 1950, H.T. Chang 4650 (SYS); Hengshan, Fangkwang Tzu, 9 May 1955, K.H. Chu 99 [00029207 (PE-image!; IBK00191088-image!; IBK00191089-image!].

Trees 20-22 m tall; with clear bole up to $15 \mathrm{~m}$, bark grey-brown. Leaves alternate, imperipinnate, 25-80 $\mathrm{cm}$ long, sparsely hairy in leaf axils or glabrous; petiole $10-25 \mathrm{~cm}$ long; petiolules $2-10 \mathrm{~mm}$; stipules very early caducous; leaflets 7-15, elliptic, oblong-lanceolate or ovate-lanceolate, slightly oblique at base, 6-26 $\times 2.5-9.0 \mathrm{~cm}$, papery in young stage, coriaceous at maturity, glabrous on both surface, sometimes hairy on midrib, lower surface glaucous, base rounded to cuneate, margin entire, acuminate to acute at apex; lateral veins $8-15$ pairs. Inflorescence $20-40 \mathrm{~cm}$ long, terminal raceme. Flowers zygomorphic, $3-5 \mathrm{~cm}$ across, showy, rose white; pedicels slender, $2-4 \mathrm{~cm}$ long, reddish green. Calyx broadly tubular, $1.5-2.3 \times 1.2-2.7 \mathrm{~cm}$ with 5 truncate lobes, pubescent on both surface, glaucous, rose white outside, with broad and prominent greenish band at regular intervals inside. Petals imbricate, broadly spathulate to obovate-cuneate, $1.8-2.0 \times$ $1.5-2.0 \mathrm{~cm}$, apex rounded and notched, base cuneate, adnate to inner side of calyx tube, with a long claw; upper petals hood like, slightly larger, covering stamens and style, pinkish white, inner surface rose pink with prominent red streaks. Stamens 8, free, 2.5-3.0 $\mathrm{cm}$, long, terete, curved downwards along with gynoecium, close together in one group, hairy at base; anther dorsifixed. Ovary broadly ellipsoid to globular, 3-4 $\mathrm{mm}$, sessile, trimerous, placentation axile, style 3-4 $\mathrm{cm}$, bent abruptly downward apically, ovary and style hairy. Fruits ellipsoid-globose to subglobose to ovoid or obovoid, 3.5-4.5 cm long and 3.3-3.5 cm wide, obscurely 3-angled, 3-valved, valves leathery thick, surface warty, pubescent; fruit stalk $2.5-3.5 \mathrm{~cm}$ long; seeds ellipsoid-globose, compressed, 1.2-2.5 × 1.2-1.8 $\mathrm{cm}$, smooth or sparsely hairy towards chalaza, yellowish orange-red. Pollens sub-oblate to oblate, tricolpate.

Flowering:-March-April.

Distribution:- India (Present Report), S China, Thailand (Santisuk, 1989); Vietnam ( Lianli Lu \& Boufford 2005); Taiwan (Lu \& al., 1986)
Status:- The species is assessed as Endangered A1cd ver. 2.3 (Sun, 1998). During the present study, we could locate only two mature trees in NNPTR.

Habitat:- Found growing in Tropical rain forests at elevation of $450 \mathrm{~m}$ in association with Dipterocarpus retusus Blume, Pterospermum acerifolium (L.) Willd., Ficus auriculatum Lour, Mesua ferrea L., etc.

Specimens examined:- India, Arunachal Pradesh, Changlang District, Namdapha National Park, 26-042017, 500 m, V.Kumar, S. Lahiri \& S. Panday 74239 (CAL!, ARUN!).

China, Hunan, 950-1100 m, Handel Mazzetti 12130 (E!, WU acc. no. WU044937-image!, WU044938image!, WU044939-image!); Pana, Changseng, 23-101930, Y. Tsiang (E !) Yunnan, Mengtze, A. Henry 10540 (K000681001!, 00050654 (GH-image!, 00095084 (USImage !). Taiwan, Yangming Shan National Park, $\mathrm{N}$ of Taipei City, SW-Central part of park along road from Chutzu-Hu (Bamboo Lake) to Tayiokeng Recreation Area, 430 m, 03-10-1989, D.E. Boufford \& al. 25251 (L0102488, L0102489, Image!); Taipei, Yangmingshan National Park, 19-08-1987, Robert F. Torne \& al. 62929 (PE 01121580- image!].

Chromosome no.: $2 \mathrm{n}=18$ (Tobe \& Peng, 1990).

Etymology:- The genus was named in honour of Dr. Emil Bretschneider, an Esthonian botanist.

Note:- The seeds of Bretschneidera sinensis are of nonendospermic nature and show low germination rate. Probably, this is one of the reasons of the its sporadic distribution in Indo-china region. Exploitation in similar region in NE India and Myanmar may further extend and fill the gaps in the distribution of this species. The showy and attractive raceme inflorescence of the species has a great potential for ornamental purpose and appears to be suitable for avenue plantation. Bretschneidera sinensis was originally described from Yunnan (China), and subsequently also collected from $\mathrm{N}$ Taiwan and $\mathrm{N}$ Thailand. Later on, B. yunshanensis was described by Chun \& How (1958) from Human and Hengshan in China and they differentiated it from $B$. sinensis on the basis of size of flowers, fruits and seeds; however, this was only a variation and merged with B. sinensis by Santisuk (1989). Botanical Survey of India is planning to propose a joint programme of propagation and conservation of this rare and interesting tree species on pilot project mode. 


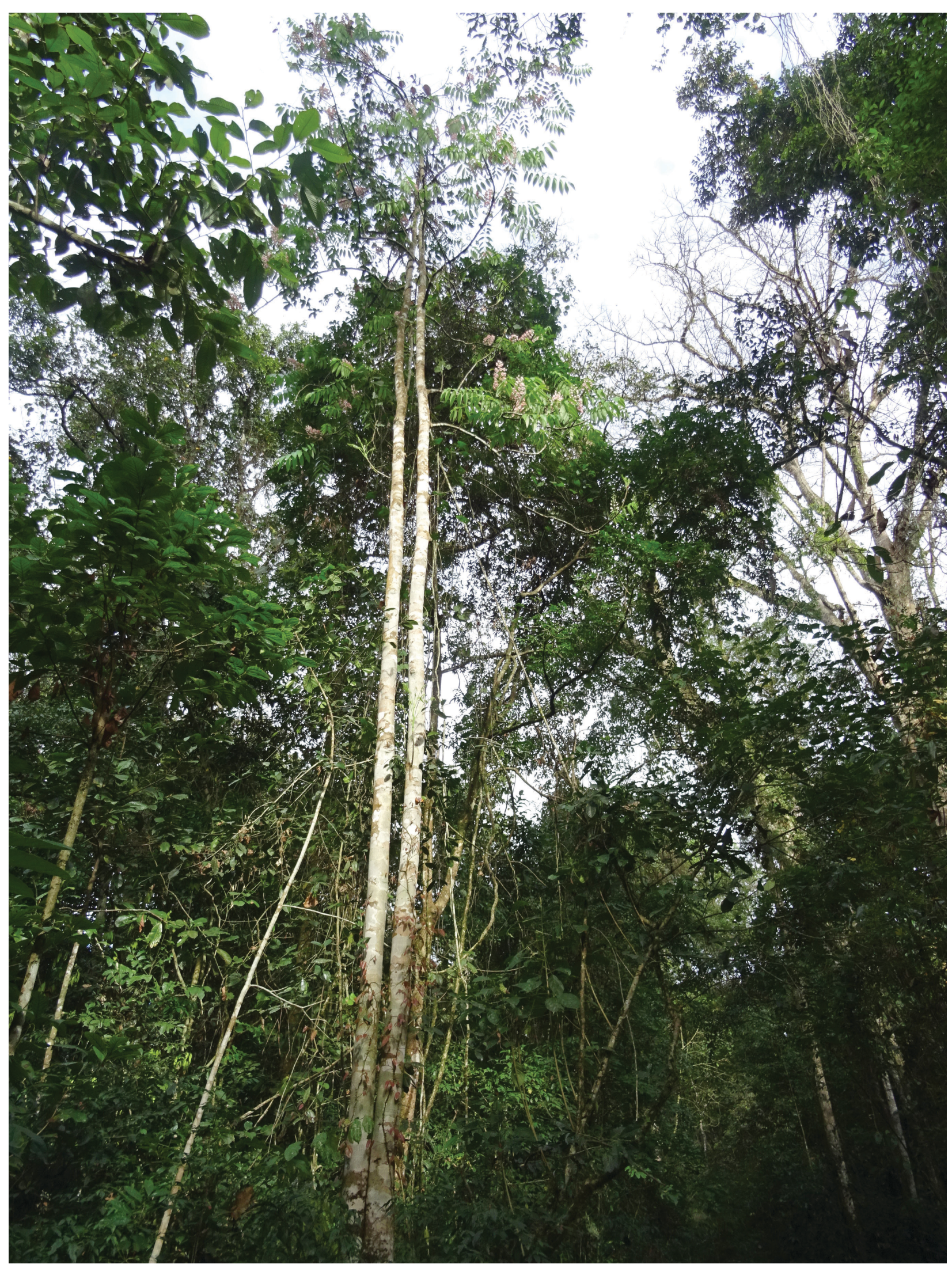

Fig. 1: Habit of Bretschneidera sinensis Hemsl. 


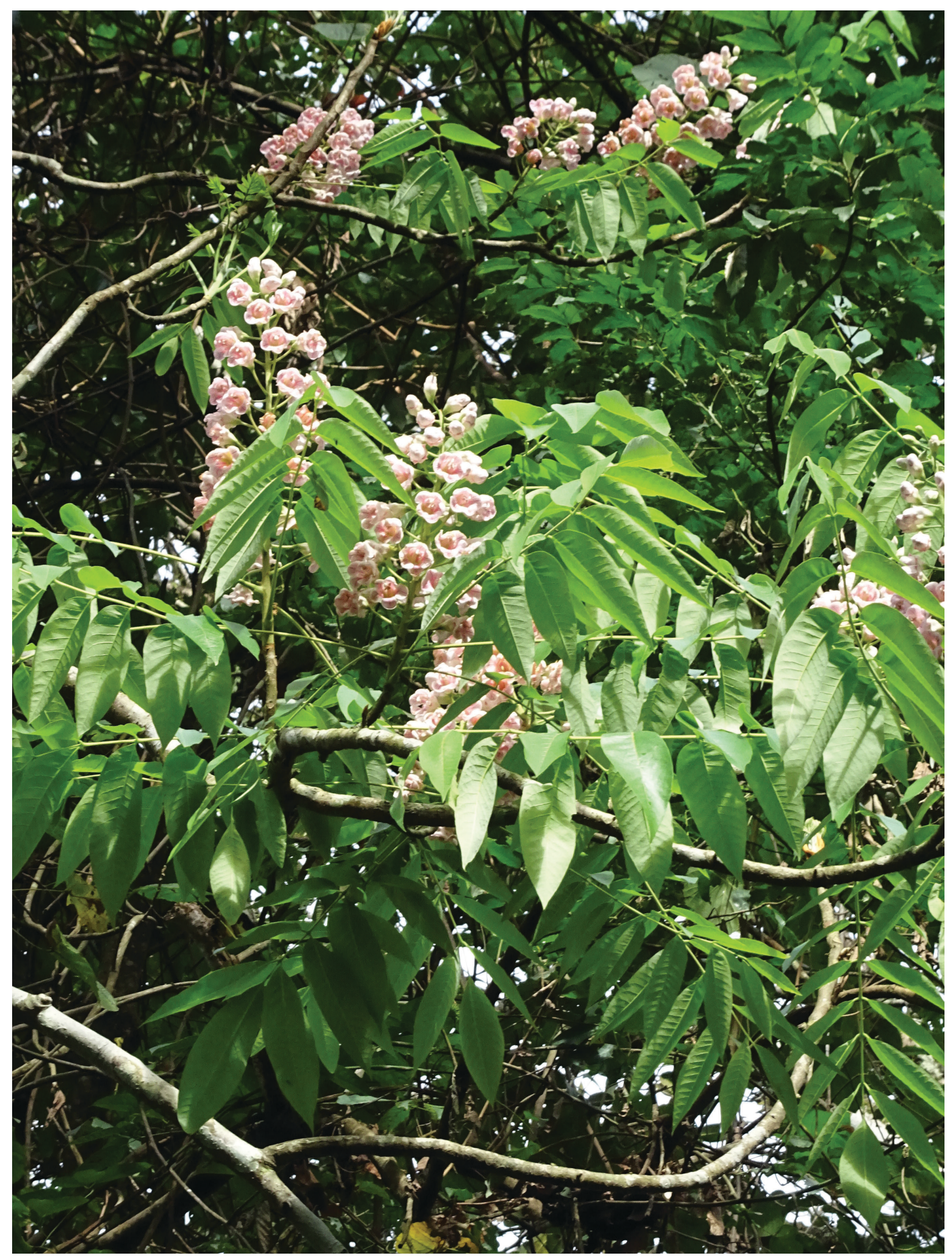

Fig. 2: Inflorescene of Bretschneidera sinensis Hemsl. showing the arrangement of the flowers. 


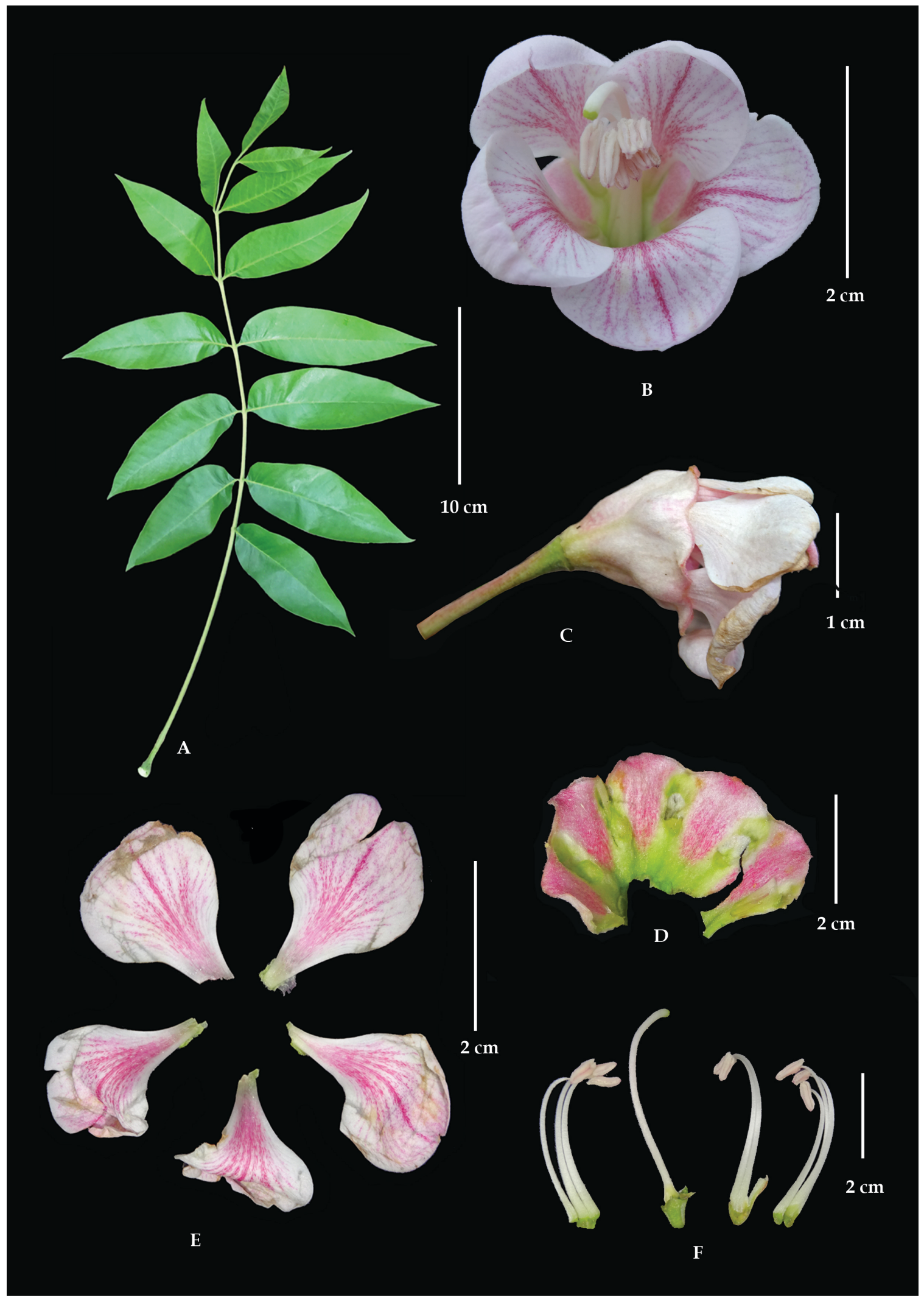

Fig. 3: Bretschneidera sinensis Hemsl. A. Leaf, B. Flower front view, C. Flower lateral view D. Calyx, opened out, adaxial view, E. Petals, F. Stamens and Pistil. 


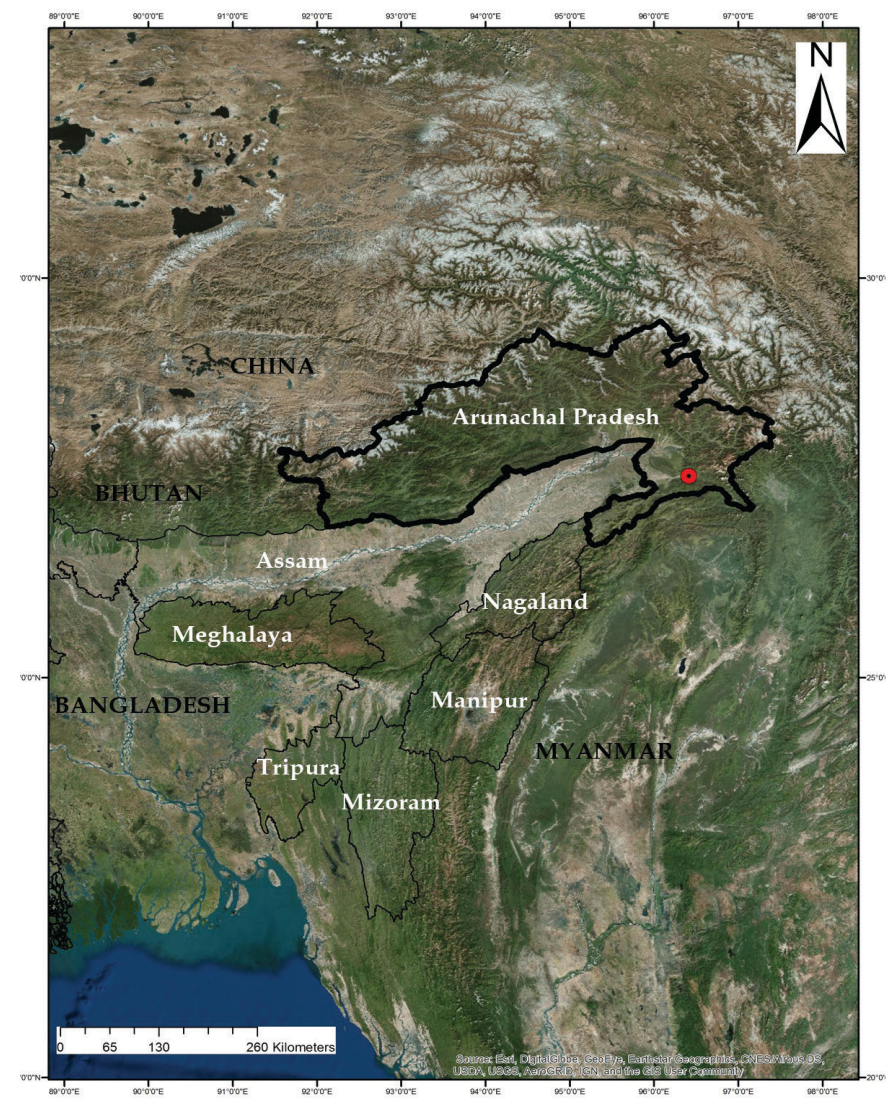

\section{ACKNOWLEDGEMENTS}

Authors are thankful to the Mountain Division MOEFCC, New Delhi for financial Assistance (File no. NMHS/2015-16/LG-05) under NMHS Scheme. Thanks are also due to the PCCF, Forest Department, Arunachal Pradesh and Project Director, Namdapha Tiger Reserve and National Park for permission and logistic support. one of us (PS) is thankful to the authorities at $\mathrm{BM}, \mathrm{E}$, and $\mathrm{K}$ for giving permission to consult collections during his recent visit. We are also thankful to Dr. Anthony R. Brach, Harvard University Herbaria, Harvard, for providing specimen images lodged at A; to Curators of $\mathrm{K}, \mathrm{WU}, \mathrm{L}, \mathrm{GH}, \mathrm{PE}, \mathrm{IBK}$ for providing specimen images on website. We also acknowledge Royal Botanic Gardens, Kew for allowing to print the digital image of the lectotype designated here. We also thank Dr. Gopal Krishna and Dr. Abhishek Bhattacharjee of Central National Herbarium (CAL) for their help during identification.

Fig. 4: Locality map of Bretschneidera sinensis in Arunachal Pradesh (Arc Map 10.5, basic version).

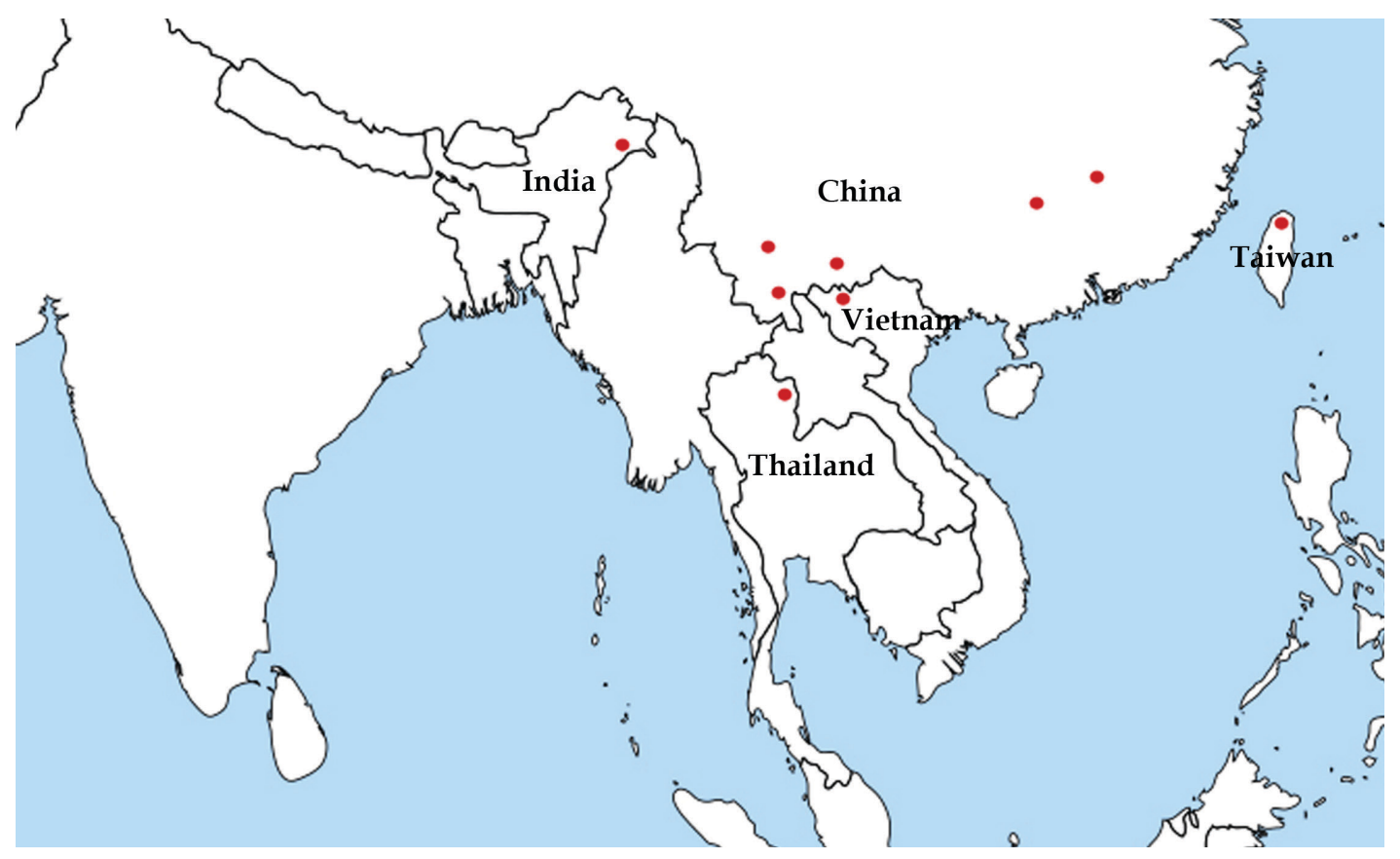

Fig. 5: Distribution of Bretschneidera sinensis Hemsl. (in Red dots) in India, China, Vietnam, Thailand \& Taiwan 


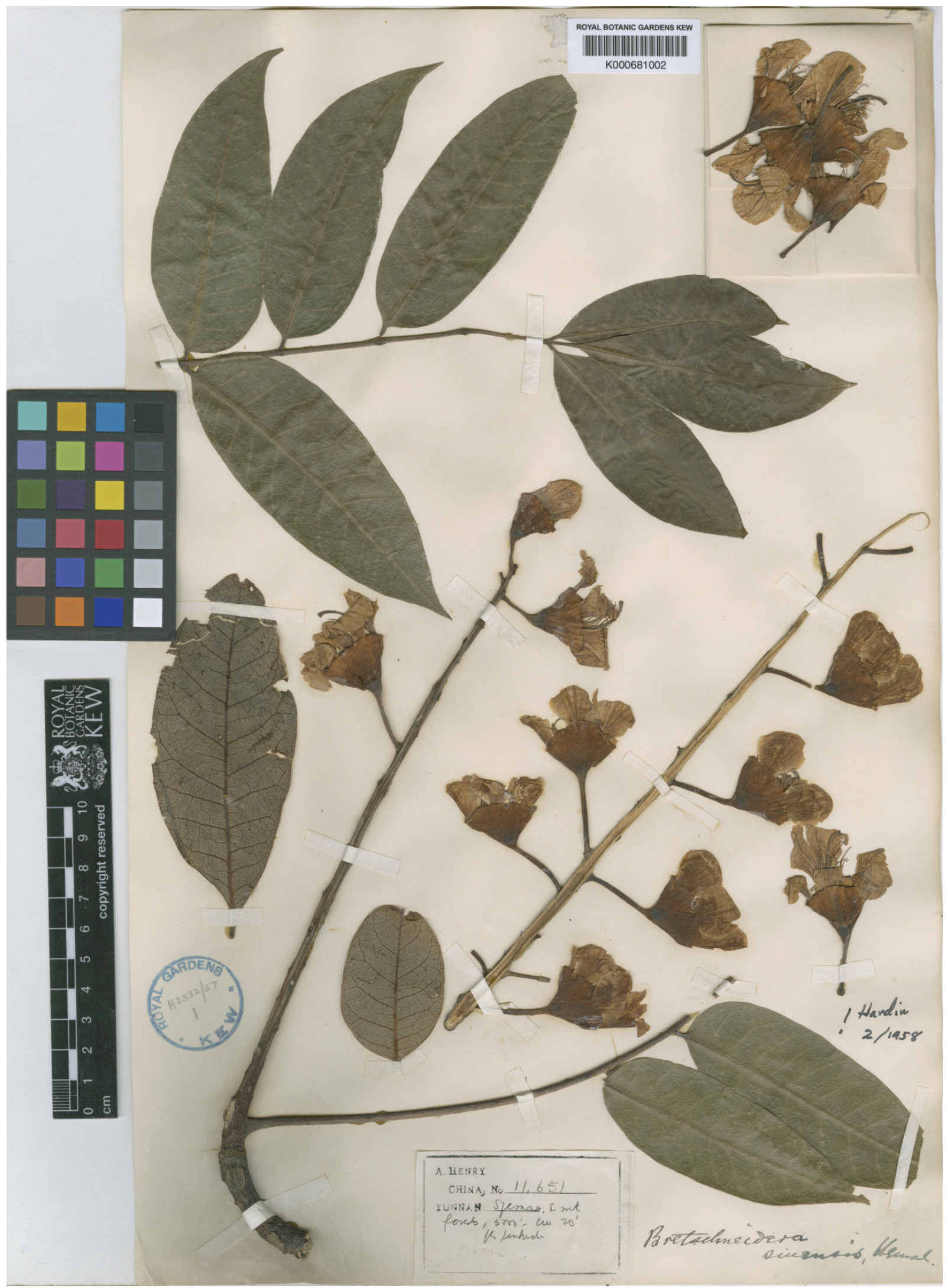

Fig. 6: Lectotype image of Bretschneidera sinensis.

( ๑ The Board of Trustees of the Royal Botanic Gardens, Kew. Reproduced with the consent of the Royal Botanic Gardens, Kew.) 


\section{REFERENCES}

APG 1998. An ordinal classification for the families of flowering plants. Ann. Missouri Bot. Gard. 85:531-553.

APG 2009. An update of the Angiosperm Phylogeny Group classification for the orders and families of flowering plants. APG III. Bot. J. Linn. Soc. 161: 105-121.

APG 2016. An update of the Angiosperm Phylogeny Group classification for the orders and families of flowering plants. APG IV. Bot. J. Linn. Soc.181: 1-20.

CARLQUIST, S. 1996. Wood anatomy of Akaniaceae and Bretschneideraceae: a case of near identity and its systematic implications. Syst. Bot. 21:607-616.

CHAUHAN, A.S., K.P. SINGH AND D.K. SINGH 1996. in (ed. P.K.Hajra) A contribution to the Flora of Namdapha Arunachal Pradesh., Botanical Survey of India, Kolkata. pp. 422.

CHRISTENHUSZ, M.J.M. AND J.W. BYNG 2016. The number of known plants species in the world and its annual increase. Phytotaxa 261(3): 201-217.

CHUN, W.Y. AND F.C. HOW 1958. Contributions to the Flora of South China (I). Acta Phytotax. Sin. 19587 (1): 1-90.

DOWELD, A.B. 1996. The carpology and taxonomic relationships of Bretschneidera (Bretschneideraceae). Acta Bot. Maladtania 21:79-90.

ENGLER, A. AND E. GILG 1919. Syllabus der Pflanzenfamilien. Gebrüder Borntraeger, Berlin.

ENGLER, A. AND E. GILG 1924. Syllabus der Pflanzenfamilien. $9^{\text {th }}$ ed. Gebrüder Berlin: Borntraeger.

GADEK, P.A., C.J. QUINN, J.E. RODMAN, K.G. KAROL, E. CONTI, R.A. PRICE, AND E.S. FERNANDO 1992. Affinities of the Australian endemic Akaniaceae: new evidence from rbcL sequences. Austral. Syst. Bot. 5: 717-724.

HEMSLEY, W.B. 1891. Bretschneidera sinensis: In: ThiseltonDyer WT, ed. Hooker's Icones Plantarum, 28(1): Pl.2708. London: Dulau \& Cie.

HOOKER, J.D. 1862. Akania In: Bentham, G. \& Hooker, J.D. Genera Plantarum: ad exemplaria imprimis in Herberiis Kewensibus servata definita vol 1(1): 409. London: L Reeve \& Co.

HUTCHINSON, J. 1926. Families of Flowering Plants-I. Dicotyledons. Clarendon Press, Oxford.

LIANLI, LU AND DAVID E. BOUFFORD 2005. Bretschneidera sinensis Hemsley In: Wu, Z.Y., Raven, PH. \& Hong,
D.Y. (Eds.) Flora of China. vol. 8.Science Press, Bejing in association with Missouri Botanical Garden, St. Louis, pp. 197.

LU, S.Y., K.S. HSU AND F.H. FAN 1986. Bretschneideraceae, a new family record for the flora of Taiwan. Quart. J. Chin. Forest. 19: 115-119.

MCNEILL, J., F.R. BARRIE, W.R. BUCK, V. DEMOULIN, W. GREUTER, D.L. HAWKSWORTH, P.S. HERENDEEN, S. KNAPP, K. MARHOLD, J. PRADO, W.F. PRUD'HOMME VAN REINE, G.F. SMITH, J.H. WIERSEMA, AND N.J. TURLAND 2012. International Code of Nomenclature for algae, fungi, and plants (Melbourne Code), Adopted by the Eighteenth International Botanical Congress Melbourne, Australia, July 2011.

RODMAN, J.E. 1991. A taxonomic analysis of glucosinolate producing plants. Part 2.Ciadistics. Syst. Bot. 16:619-629.

RODMAN, J.E., K.G. KAROL, R.A. PRICE AND K.J. SYTSMA 1996. Molecules, morphology, and Dahlgren's expanded order Capparales. Syst. Bot. 21: 289-307.

RONSE, DE CRAENE L.P. T.Y.A YANG, P. SCHOLS AND E.F. SMETS 2002. Floral anatomy and systematics of Bretschneidera (Bretschneideraceae). Bot. J. Linn. Soc. 139: 29-45.

SANTISUK, T. 1989. The monotypic family Bretschneideraceae newly recorded for Thailand. Nat. Hist. Bull. Siam Soc. 37: 173-176.

SOLEREDER, H. 1892. Über die Staphyleaceengattung Tapiscia Oliv. Ber. Dtsch. Bot. Ges. 10: 545-551.

STAPF, O. 1912. Akaniaceae: A new family of Sapindales. Bull. Misc. Inform. 1912: 378-380.

SUN, W. 1998. Bretschneidera sinensis. The IUCN Red List of Threatened Species 1998: e.T32324A9697750. http://dx.doi. org/10.2305/IUCN.UK.1998.RLTS.T32324A9697750.en. (accessed May 25, 2017).

THE PLANT LIST 2016. Version 1.1. Published on the Internet; http://www.theplantlist.org/ (accessed May 25, 2017).

TOBE, H. AND C.I. PENG 1990. The embryology and taxonomic relationships of Bretschneidera (Bretschneideraceae). Bot. J. Linn. Soc.103: 139-152.

TOBE, H. AND P.H. RAVEN 1995. Embryology and relationships of Akania (Akaniaceae). Bot. J. Linn. Soc. 118:261-274. 